\title{
Deregulated ephrin-B2 signaling in mammary epithelial cells alters the stem cell compartment and interferes with the epithelial differentiation pathway
}

\author{
PHILIP KAENEL, MILICA ANTONIJEVIC, STEFANIE RICHTER, SAMUEL KÜCHLER, \\ NORA SUTTER, CARLOS WOTZKOW, ROBERT STRANGE and ANNE-CATHERINE ANDRES \\ Department of Clinical Research, University of Bern, Tiefenaustrasse 120c, CH-3004 Bern, Switzerland
}

Received July 28, 2011; Accepted September 1, 2011

DOI: $10.3892 /$ ijo.2011.1238

\begin{abstract}
Cancer most probably originates from stem/progenitor cells and exhibits a similar cell hierarchy as normal tissues. Moreover, there is growing evidence that only the stem cells are capable of metastasis formation. We have previously shown that overexpression of a dominant negative ephrin-B2 mutant interferes with mammary gland differentiation and confers a metastatic phenotype to NeuT-induced mammary tumors with an increase in cells with stem/progenitor characteristics. To investigate the role of ephrin-B2 in the control of the mammary stem cell niche, we analyzed the mammary stem and progenitor cell populations in transgenic mice overexpressing the mutant ephrin-B2. Quantification by FACS analysis revealed a significant increase of cells in the basal/alveolar cell-, the bi-potent progenitor- and the stem cell-enriched fractions. Moreover, the supposed precursors of estrogen receptor-positive cells were elevated in the stem cell-enriched fraction. In contrast, the epithelium from transgenic mice overexpressing the native ephrin-B2 gene showed an augmentation of the luminal celland the bi-potent progenitor-enriched fractions. Repopulation assays revealed that the epithelial cells of truncated ephrin-B2 transgenic epithelial cells have a higher regeneration capacity than those of controls and of native ephrin-B2 transgenic mice, confirming the augmentation of stem cells. Morphologically, these outgrowths exhibited impaired basal/luminal compartmentalization and epithelial polarization. These results demonstrate that deregulated ephrin-B2 expression interferes with the regulation of the stem cell niche and leads to a shift of the differentiation pathway and may thereby contribute to the acquisition of the metastatic phenotype long before carcinogenic growth becomes apparent.
\end{abstract}

Correspondence to: Professor Anne-Catherine Andres, Department of Clinical Research, Tiefenaustrasse 120c, CH-3004 Bern, Switzerland E-mail: anne-catherine.andres@dkf.unibe.ch

Key words: CD49f CD24, estrogen receptor, mammary gland, repopulation assay, transgenic mice

\section{Introduction}

Carcinogenesis in the mammary gland can give rise to a variety of breast tumors which can generally be subdivided into luminal and basal type. Diagnosis, prognosis and specific therapy rely on precise classification of tumors. Considering the aggressiveness of carcinogenic diseases and their metastatic potential, it is widely supported that this can be attributed to a small subset of cells mainly responsible for secondary tumor formation but also relapse after therapy (1). This evoked the ongoing discussion of the cancer stem cell hypothesis suggesting stem and progenitor cells to be the likely targets for cell transformation in cancerogenesis. Morphogenesis and homeostasis of the mammary gland as well as carcinogenesis reveal differentially regulated stem and progenitor cell niches independent of the developmental status of the tissue and endocrine and paracrine signaling cues (2). Thus, it appears crucial to further elucidate the regulatory mechanisms of the stem cell niche in order to identify pathways which are acquired or hijacked by tumor-initiating cells narrowing down more specific therapeutical targets. We previously identified cells responsible for a metastatic phenotype of NeuT induced mammary tumors in mouse models with disturbed EphB4/ephrin-B2 signaling (3). Furthermore, we previously described morphological disturbances in mammary development $(4,5)$. In this study, we aimed to point out effects of deregulated signaling involving ephrin-B2 on the regenerative capacity of mammary epithelial cells and analyze morphological changes to identify mechanisms by which ephrin-B2 affects normal mammary gland development.

The hormonal status of estrogen, progesterone, growth hormone and prolactin coordinates the developmental events through employing local, paracrine mediators (6). These influence cells in different ways often by modifying their microenvironment. In this way, the complex cell and tissue homeostasis involved in glandular regeneration through repeated estrous cycles and developmental cycles at pregnancy, lactation and involution is organized and adapted to the required functional state. In the carcinogenic process, alterations in the microenvironment, instrumental in governing the development during the estrous cycle, pregnancy, lactation and involution, can interfere with essential regulatory mechanisms leading to tumorigenic cells (7). 
With regard to ductal growth which mainly occurs during puberty, the growing duct requires a specialized structure to invade the fat pad, the terminal end bud (TEB). It also needs to reorganize the cells at the trailing end of the TEB to form the bilayer of luminal epithelial and myoepithelial cells of a mammary duct (8). The outgrowth of TEBs requires stromal signals initiated by hormonal stimulation, whereas cell contact and polarity states of body cells in the TEB determine cell survival and differentiation fate. Finally, the physical barrier of fibrous tissue serves as an initiator of bifurcations, leading to branching events $(6,9)$.

Cell interactions are essential not only in growing structures but also in the homeostasis of the mammary tissue. Turnover of epithelial cells without breaking up the functional architecture depends on dynamic junctional interplay between epithelial cells (10) as well as on targeted cell elimination by intraepithelial macrophages (11). The process of regeneration and tissue homeostasis also requires activation of dormant tissue and the recruitment of cells from a mammary-specific stem cell population in their niche. This requires a specialized organization of the stem cell niche, involving signal-responsive sensory epithelial cells and the stem cell itself (2). Current knowledge suggests an evolution of stem cell regulation which correlates with the overall state of mammary development. Prepubertally, the niche remains independent of ovary hormonal regulation and is thought to be controlled by epithelial-mesenchymal cross-talk governed by PTHrP and BMP4 $(12,13)$ and also involving FGF and Wnt signaling $(14,15)$.

At the onset of puberty and at pregnancy, mammary stem cells are regulated by ovarian and pituitary hormone signals. Since the adult stem cells are thought to be hormone receptor negative, their hormone-dependent activation must occur in a paracrine manner via specific sensor cells in the niche (2). Mechanisms contributing to cell regulation in this microenvironment are thus downstream of progesterone or estrogen signaling (16-18) and include among others Wnt, FGF, EGF and RANK signaling (19-22), integrin and E-cadherin mediated cell-matrix or cell-cell interactions $(23,24)$, and also MMP and TGF $\beta$ mediated ECM remodelling $(25,26)$. Adhesion, cell polarity, survival, dormancy, apoptosis, proliferation and differentiation are all potential cellular responses resulting from these interactions which contribute to or are decisive for tissue organization. Although extensive research has led to the elucidation of a mammary epithelial differentiation hierarchy (27-29), many aspects of the mechanisms involved in the control of the stem cell niche, the release of precursor cells and the determination of cell fate remain to be investigated.

Members of the Eph receptor family and their cognate ligands, the ephrins, have been implicated in the regulation of cell shape, attachment and motility. Several Eph receptors have been reported to either suppress or promote integrin activity by affecting focal adhesion complexes via FAK or paxillin, through regulation of small GTPases R-ras and Rap1 activity or by interaction with the phosphatidylinositol-3-kinase pathway (30). In the intestinal epithelium the $\beta$-catenin/Tcf complex regulates EphB receptor gene transcription and thus, expression seems to be modulated by Wnt signaling. EphB and ephrin-B genes are expressed in reciprocal gradients along the crypt villus axis and appear to define the borders of the intestinal stem cell niche (31). Similarly, E-cadherin mediated cell-cell adhesion can also regulate Eph/ephrin expression and membrane localization and vice versa $(32,33)$. These findings all link Eph and ephrin molecules to pathways which are closely related to the regulation of mammary cell fate and differentiation.

In previous work, we demonstrated that EphB4 and ephrin-B2 play major roles in mammary gland morphogenesis and tissue homeostasis $(4,5,34,35)$. Overexpression of the native ephrin-B2 gene resulted in precocious differentiation and increased secretory activity. In contrast, expression of a truncated form of ephrin-B2, incapable of reverse signaling in mammary epithelium, resulted in delayed differentiation and aberrant tissue architecture. Myoepithelial cells formed an irregular layer around the epithelial cells and borders in between could not be clearly delineated. Consequently, secretory activity and also fat droplet formation were decreased. In addition to the aberrant epithelial morphology, these mammary glands contained a highly irregular vasculature with many blind-ended capillaries and conferred a metastatic phenotype to NeuT induced mammary tumors (4). In this study, we investigate the impact of the deregulated ephrin-B2 signaling on the homeostasis of the mammary stem cell niche and the differentiation pathway of the stem cell progenitors. Our results reveal that deregulated ephrin-B2 signaling interferes with the binary decision pathway during progenitor cell differentiation. Moreover, the expression of the dominant negative ephrinB2 mutant, but not the native ephrin-B2 gene, increases the mammary stem cell pool indicating that the reverse ephrin-B2 signaling is indispensable for the homeostasis of the mammary epithelial stem cell niche.

\section{Materials and methods}

Transgenic lines. The establishment of the ephrin-B2 and $\Delta$ ephrinB2 transgenic mouse lines has been described previously (4). Briefly, for the $\Delta$ ephrinB2 line a fragment encoding the intracellular part containing the five conserved tyrosine residues for reverse signaling was removed from the murine ephrin-B2 cDNA. The remaining fragment encompasses the intact sequences for the transmembrane region and the extracellular part, thus retaining the capability of correct membrane localization, interaction with EphB4 and dimerization with endogenous ephrin-B2. Forward signaling therefore remains possible whereas reverse signaling is abolished. The truncated as well as the native ephrin-B2 cDNA was placed under the control of the MMTV-LTR promoter for either mouse line and transgenic mice were established by pronuclear injection. Transgenic mice were crossed over 6 generations with inbred C57/B16 mice (Charles River Wiga, Sulzfeld, Germany) in order to reduce complexity of the genetic background. All animal studies were conducted according to the institutional ethics guidelines.

Cell isolation, FACS analysis and cell sorting. The inguinal \#4 mammary glands were removed from resting adult female virgin mice. After mechanical dissection, the tissue was transferred to enzymatic digestion in complete EpiCult ${ }^{\circledR}$-B medium supplemented with collagenase/hyaluronidase and 5\% (v/v) fetal calf serum (all reagents; StemCell Technologies, Grenoble, France). Generation of a single cell suspension for 
antibody staining was performed according to the protocol of the manufacturer.

The antibodies used for flow cytometry analysis and cell sorting were purchased from Biolegend (San Diego, CA, USA) and included biotinylated TER119 (clone TER-119), biotinylated CD31 (clone MEC13.3), biotinylated CD45 (clone 30-F11), Streptavidin-PE/Cy7, CD49f-FITC (clone GoH3), CD24-PE (clone M1/69), EpCAM-APC (clone G8.8), Sca-1-APC (clone E13-161.7) and CD49b-Pacific Blue ${ }^{\mathrm{TM}}$ (clone DX5). Isotype controls were performed with the corresponding mouse IgG1 $\kappa$ Isotype Control antibodies from Biolegend. Compensation was performed using the $\mathrm{BD}^{\mathrm{TM}}$ CompBeads compensation particles set (BD Biosciences, San Jose, CA, USA).

For staining, cells were incubated at $5-10 \times 10^{5}$ cells $/ \mathrm{ml}$ in PBS, $2.5 \%(\mathrm{v} / \mathrm{v})$ fetal calf serum, $10 \mathrm{mM}$ EDTA, $0.2 \%(\mathrm{w} / \mathrm{v})$ sodium azide containing the primary antibodies for $25 \mathrm{~min}$ at $4^{\circ} \mathrm{C}$ and subsequently $15 \mathrm{~min}$ at $4^{\circ} \mathrm{C}$ with the secondary antibody. Analysis was carried out with FACSDiva software on a BD LSRII Special Order System (BD Biosciences) and cells were sorted on a BD FACSAria (BD Biosciences). Samples were primarily gated on forward- and side-scatter. Contaminating endothelial and hematopoietic cells were excluded by gating for CD31, CD45 and TER119 negative cells. Endothelial and hematopoietic lineage negative cells were either analyzed or sorted according to their CD49f, CD24, EpCAM, Sca-1 and CD49b expression.

Mammary fat pad cell transplantations and repopulation analysis. Mammary glands of 18-21 days old C57/B16 mice (Charles River Wiga) were cleared of endogenous epithelium according to the procedure introduced by DeOme (36). Test cells were prepared as described above and suspended at required concentrations in DMEM medium (Sigma Aldrich, Buchs, Switzerland) with $2 \%$ (v/v) FCS. Into each cleared fat pad, 5-10 $\mu \mathrm{l}$ were injected. After 8 weeks of growth, the mice were sacrificed, mammary glands were excised and fixed in Carnoy's solution for $4 \mathrm{~h}$. Subsequently, mammary glands were rehydrated and stained with Carmine Alum for outgrowth analysis. After recording, mammary glands were embedded in paraffin and sectioned for microscopy.

Immunohistochemistry and laser scanning microscopy. Hematoxylin and eosin (Merck, Darmstadt, Germany) stainings were performed as previously described (4). Antibodies used for analysis included E-cadherin (BD Biosciences, clone 36/E-cadherin), $\beta$-catenin (BD Biosciences, clone $14 / \beta$-catenin), MUC-1 (OriGene, Rockville, MD, USA, clone EP1024Y), K14 (Novus Biologicals, Littleton, CO, USA, polyclonal), K18 (Novus Biologicals, clone C-04), K19 (M-17) (Santa Cruz Biotechnology, Santa Cruz, CA, USA, polyclonal), EpCAM (OriGene, clone 144), Par-3 (Proteintech Group, Manchester, UK, polyclonal), ZO-1 (Millipore, Zug, Switzerland, clone R40.76), ER $\alpha$ (Novocastra, Newcastle, UK, clone 6F11), Ki67 (Novus Biologicals, clone Sp6), activated caspase 3 (Cell Signaling Technology, Danvers, MA, USA, polyclonal), and Sca-1 (BD Biosciences, clone E13-161.7). Tissue preparation and immunohistochemistry were done as described (4) and epitope retrieval was done either by microwaving in citrate buffer pH 5.5 (E-cadherin, $\beta$-catenin, MUC-1, $\mathrm{ER} \alpha$, activated caspase 3 ) or in Tris-EDTA (TE) buffer $\mathrm{pH} 8.0$
(Par-3, ZO-1), alternatively Proteinase K (Roche Diagnostics, Rotkreuz, Switzerland) digestion for $5 \mathrm{~min}$ at $37^{\circ} \mathrm{C}$ was used (K14, K18, K19, EpCAM, Ki67, Sca-1).

For laser scanning microscopy the secondary antibodies included anti-mouse IgG Alexa Fluor ${ }^{\circledR} 488$ (Invitrogen, Basel, Switzerland), anti-rat IgG Alexa Fluor 488 (Invitrogen), anti-rat IgG Cy3 (Millipore), anti-goat IgG FITC (Millipore), anti-goat IgG Cy5 (Millipore) and anti-rabbit IgG Cy5 (Millipore) antibodies. After incubation with primary antibodies overnight the sections were washed 3 times with TBS and labelled secondary antibodies were applied in mixtures according to the demanded combinations and at the concentrations indicated by the manufacturer. Sections were incubated for 2-4 h at RT in the dark, rinsed, stained with DAPI if required (Sigma Aldrich), embedded in Mowiol (Sigma Aldrich) and analyzed using a LSM Zeiss Meta 510 (Carl Zeiss, Jena, Germany).

\section{Results}

Our previous study indicated that overexpression of a truncated dominant negative ephrin-B2 mutant ( $\Delta$ ephrinB2) not only promotes metastasis of mammary tumors but also results in a tumor phenotype accompanied by a preponderance of cells with stem/progenitor cell characteristics (3). We used this transgenic mouse line and transgenic mice overexpressing the native ephrin-B2 gene (ephrinB2) (4) to investigate if ephrin-B2 signaling is involved in the control of the mammary stem cell compartment and epithelial differentiation. RT-PCR analysis revealed that the transgene is expressed in both the luminal $\left(\mathrm{CD} 24^{+} \mathrm{CD} 49^{\text {flow }}\right)$ and basal $\left(\mathrm{CD} 24^{+} \mathrm{CD} 49 \mathrm{f}^{+}\right)$epithelial cell populations (data not shown). The mammary epithelium was analyzed by a dual approach: the quantitative evaluation of defined mammary epithelial cell populations and the functional analyses of the capacity of these populations to repopulate an epithelial-free mammary fat pad.

Truncated ephrin-B2 expression leads to an increase in mammary stem cells. Flow cytometric analyses allowed identification of distinct cell populations and the definition of a differentiation hierarchy in the mammary epithelium. In particular, CD24 and CD49f expression identifies luminal cells $\left(\mathrm{CD} 24^{+} / \mathrm{CD} 49^{\text {low }}\right)$, basal cells $\left(\mathrm{CD} 24^{+} / \mathrm{CD} 49 \mathrm{f}^{+}\right)$, a cell population enriched in bi-potent progenitor cells $\left(\mathrm{CD} 24^{+} / \mathrm{CD} 49 \mathrm{f}^{++}\right)$as well as a population enriched in stem cells $\left(\mathrm{CD} 24^{\text {low }} / \mathrm{CD} 49 \mathrm{f}^{++}\right)(29)$. Mammary glands of adult virgin wild-type and transgenic females were dissociated into single cell suspension and endothelial and hematopoietic cells were excluded by FACS using the lineage markers CD31, CD45 and TER119. Lineage negative cells were subsequently separated according to their CD49f and either CD24 or EpCAM expression levels and quantified. The use of EpCAM allows a more distinct separation of individual populations, whereas CD24 is established for cell sorting and functional assays. Basal i), luminal ii), CD24 ${ }^{\text {low }}\left(\right.$ EpCAM $\left.^{\text {low }}\right) /$ CD $49 \mathrm{f}^{++}$stem cell-enriched iii) and CD24 ${ }^{+}\left(\right.$EpCAM $\left.^{+}\right) / \mathrm{CD} 49 \mathrm{f}^{++}$ bi-potent progenitor-enriched populations iv) were defined as shown in Fig. 1A. Analyses using either CD24 or EpCAM expression led to equivalent results (Fig. 1A and B). The quantification of the cells in these populations revealed that overexpression of the native ephrin-B2 gene led to a significant increase of cells in the luminal $(\mathrm{p}=0.0002)$ and the bi-potent 
A
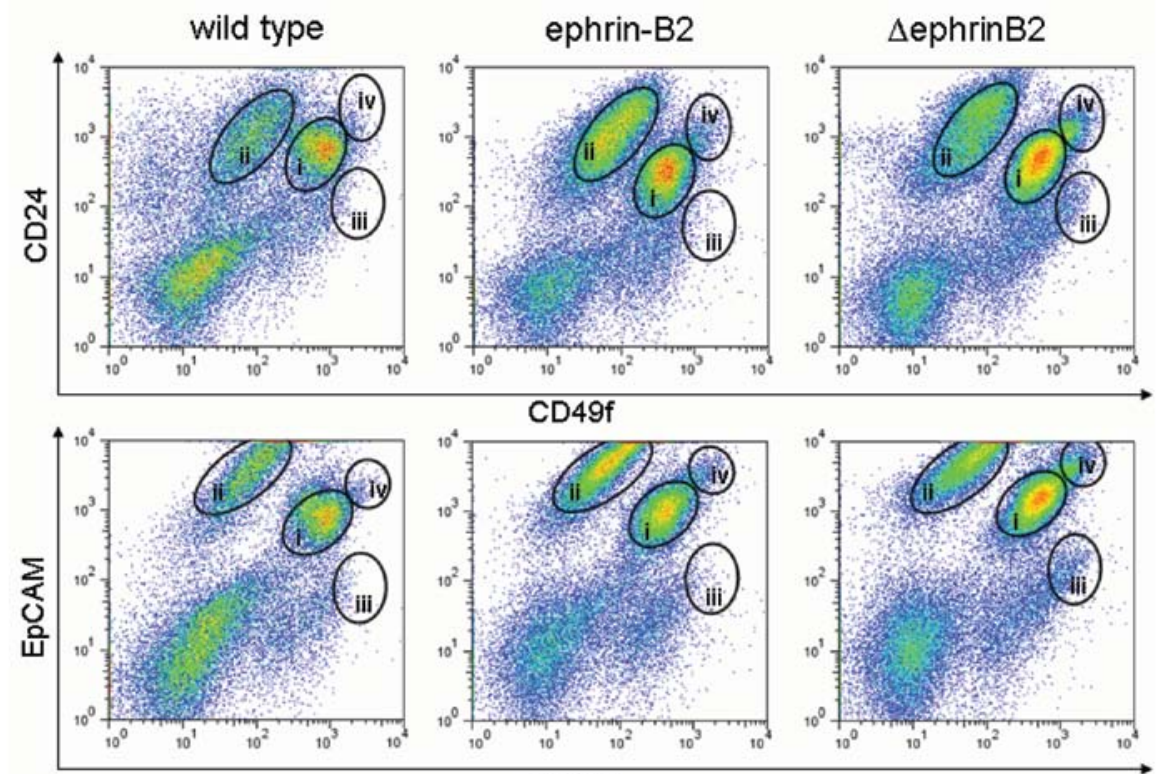

$\mathrm{CD} 49 \mathrm{f}$

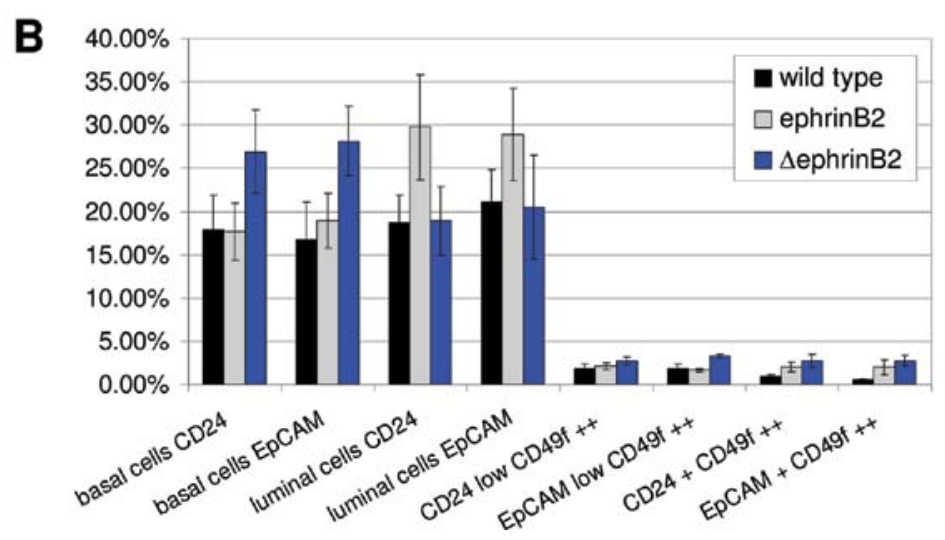

Figure 1. Quantification of epithelial cell populations in mammary glands of wild-type, ephrinB2 and $\Delta$ ephrinB2 mice by flow cytometry. (A) Cell populations in lineage negative cells (excluding endothelial and hematopoietic cells) were identified by plotting CD49f either against CD24 (top row) or EpCAM (bottom row), both giving equivalent results. Populations of interest included basal cells (i: CD24 ${ }^{+} \mathrm{CD}_{4} 4 \mathrm{f}^{+}$), luminal cells (ii: $\mathrm{CD} 24^{+} \mathrm{CD} 49 \mathrm{flow}$ ) and two populations enriched for potent progenitor cells (iv: $\mathrm{CD} 24^{+} \mathrm{CD} 49 \mathrm{f}^{++}$) or stem cells (iii: $\mathrm{CD} 24^{\text {low }} \mathrm{CD} 49 \mathrm{f}^{++}$). The same populations were also identified using EpCAM instead of CD24 together with CD49f. (B) Quantification of the populations gated with CD49f and either CD24 or EpCAM as shown in A. Bars represent standard deviation, $\mathrm{N}=6$.

progenitor cell fractions ( $\mathrm{p}=0.0001)$ (Fig. 1B). In contrast, the imbalanced ephrin-B2 reverse signaling in mammary epithelium of $\Delta$ ephrinB2 mice resulted in significant enrichment of basal cells $(\mathrm{p}=0.0005)$. In addition, significantly increased cell numbers were found in the bi-potent progenitor-enriched cell population compared to wild-type $(\mathrm{p}<0.0001)$, and also to ephrinB2 mammary glands ( $\mathrm{p}=0.04)$. Interestingly, also the stem cell-enriched cell population contained significantly more cells than the respective fractions of wild-type or native ephrin-B2 transgenic mammary glands (Fig. 1B, p=0.001 and $\mathrm{p}=0.004$, respectively) suggesting that the mammary epithelium of $\Delta$ ephrinB2 females is enriched in stem cells.

The expression profile of cell surface markers itself is not sufficient proof for the identification of a cell as stem cell. Functional assays are necessary to demonstrate their presence in a given cell population. For functional analyses we used the mammary gland repopulation assay. Mammary epithelial cells were prepared from transgenic and wild-type virgin adult mice and injected into \#4 mammary fat pads of 3 week old C57/B16 females cleared of their endogenous mammary epithelium. Cells were injected at different concentrations $\left(10^{3}\right.$, $10^{4}, 10^{5}$ ) and after 8 weeks, the animals were sacrificed and the implanted mammary glands analyzed for epithelial outgrowth. This regeneration time is not sufficient for a high repopulation frequency in wild-type B16/C57 mice, but highlights the enhanced repopulation capacity of the $\triangle$ ephrinB2 cells. With a longer regeneration period of 12 weeks or hormonal stimulation by pregnancy, a take rate of close to $100 \%$ was achieved in the wild-type controls injecting $10^{4}-10^{5}$ cells (data not shown).

For both transgenic and wild-type cell preparations, little correlation between the number of injected cells and outgrowth frequency was seen (Table I). This may be due to the fact that, although the recipient mice were of the same strain, they were not syngeneic and an immune response could have been elicited 
Table I. Repopulation frequency at different concentrations of epithelial cells isolated from wild-type, ephrinB2 and $\Delta$ ephrinB2 mammary glands injected into wild-type cleared fat pads.

\begin{tabular}{lrcccc}
\hline Strain & Injected cells & Ductal tree & Single parenchymal structures & Cell clumps & No growth \\
\hline Wild-type & 100.000 & $3 / 22$ & $3 / 22$ & $9 / 22$ & $7 / 22$ \\
& 10.000 & $2 / 16$ & $0 / 16$ & $10 / 16$ & $4 / 16$ \\
& 1.000 & $3 / 18$ & $4 / 18$ & $3 / 18$ & $8 / 18$ \\
ephrinB2 & 100.000 & $1 / 11$ & $2 / 11$ & $6 / 11$ & $2 / 11$ \\
& 10.000 & $1 / 11$ & $3 / 11$ & $2 / 11$ & $5 / 11$ \\
& 1.000 & $0 / 11$ & $2 / 11$ & $7 / 11$ & $2 / 11$ \\
SephrinB2 & 100.000 & $4 / 11$ & $2 / 11$ & $3 / 11$ & $2 / 11$ \\
& 10.000 & $3 / 9$ & $1 / 9$ & $3 / 9$ & $2 / 9$ \\
& 1.000 & $2 / 6$ & $2 / 6$ & $2 / 6$ & $0 / 6$ \\
\hline
\end{tabular}

Table II. Repopulation frequency of sorted epithelial cells isolated from wild-type and $\Delta$ ephrinB2 mammary glands injected into wild-type cleared fat pads.

\begin{tabular}{lcccc}
\hline Injected cells & Strain & Outgrowth & Cell clumps & No growth \\
\hline $\mathrm{CD}^{2} 4 \mathrm{f}^{++} /$ & Wild-type & $1 / 13$ & $12 / 13$ & $0 / 13$ \\
$\mathrm{CD}^{\text {low }}$ & $\Delta$ ephrinB2 & $11 / 24$ & $12 / 24$ & $1 / 24$ \\
$\mathrm{CD}^{2} 9 \mathrm{f}^{++} /$ & Wild-type & $2 / 8$ & $5 / 8$ & $1 / 8$ \\
$\mathrm{CD}^{+} 4^{+}$ & $\Delta$ ephrinB2 & $2 / 11$ & $9 / 11$ & $2 / 11$ \\
Luminal/ & Wild-type & $0 / 15$ & $13 / 15$ & $2 / 12$ \\
basal cells & $\Delta$ ephrinB2 & $0 / 15$ & $12 / 15$ & $3 / 12$ \\
\hline
\end{tabular}

with high numbers of injected cells. Outgrowth was classified either as ductal tree when a considerable area of the fat pad was occupied by an epithelial tree or as single parenchymal structure when the outgrowth was limited but clearly identifiable as epithelial network structure. In wild-type animals, a ductal tree was observed in $14 \%$ and single parenchymal structures in $12 \%$ of implantations. Often (39\%), a part of injected cells survived in the tissue as clumps, which were not able to grow or differentiate (Table I). Implantation of native ephrin-B2 transgenic mammary epithelial cells resulted in a frequency of ductal trees (6\%), single parenchymal structures (21\%) and clumps (45\%) similar to the wild-type situation. In contrast, the frequency of ductal trees $(35 \%)$ was significantly higher in $\triangle$ ephrinB2 derived outgrowths, whereas no growth at all was more rare (Table I). These results indicate that indeed the mammary epithelium of the $\Delta$ ephrinB2 animals contains a higher number of cells capable of reconstituting an entire epithelium.

In order to analyze which cell population is responsible for the observed outgrowth and increased repopulation frequency of the $\Delta$ ephrinB2 cells, cells from this strain and from wild-type controls were sorted according to the CD24/ CD49f expression levels as defined in Fig 1A. The different cell populations injected included the $\mathrm{CD} 24^{\text {low }} / \mathrm{CD} 49 \mathrm{f}^{++}$stem cell-enriched fraction, the $\mathrm{CD} 24^{+} / \mathrm{CD} 49 \mathrm{f}^{++}$bi-potent progenitor- enriched fraction as well as the luminal and basal cell fractions. From the stem cell-enriched fraction, 100 cells were injected, whereas from the other populations 100 and 1000 cells were used. Outgrowth from wild-type epithelial cells was observed in $8 \%$ of injections with the stem cell-enriched fraction and in $25 \%$ of injections of the progenitor-enriched fraction. In contrast, outgrowths developed from $48 \%$ of injections of the $\Delta$ ephrinB2 stem cell-enriched fraction. This was significantly higher than in wild-type, whereas the repopulation frequency from the progenitor-enriched fraction was comparable to wildtype with $18 \%$ outgrowths. In this fraction, outgrowth was only observed from 1,000 injected cells for both wild-type and transgenic cells. No outgrowth could be seen after injection of cells from the basal or luminal cell fractions from both wild-type and transgenic mammary glands (Table II). These results suggest that not only is the stem cell-enriched fraction increased in the mammary glands of $\Delta$ ephrinB2 animals but also that this fraction contains more stem cells than that isolated from wild-type animals.

Truncated ephrin-B2 expression interferes with the differentiation pathway. In order to investigate the morphology of the outgrowths repopulated mammary glands were analyzed by whole mount staining, hematoxylin/eosin staining, immunohistochemical and confocal microscopical analyses. Wholemount staining of outgrowths from wild-type epithelial cells showed a typical ductal tree with TEBs at the tips of the growing ducts (Fig. 2A). Branching and the formation of alveoli were also evident. This regular pattern of outgrowth was also observed after implantation of ephrinB2 mammary epithelial cells (Fig. 2B). In contrast, outgrowths from $\Delta$ ephrinB2 epithelial cells were characterized by extensive growth and branching activity. Alveolar structures were frequent at the expense of TEBs (Fig. 2C). In addition, ducts were often crossing each other or grew into intimate contact with each other, suggesting impaired contact inhibition or spatial organization. Strikingly, massive ductal thickening reminiscent of hyperplastic nodules was frequently seen at branching points. Hematoxilin/eosin staining revealed a normal architecture of ductal structures with a clear bilayer of cells surrounding a lumen in outgrowths derived from wild-type and ephrinB2 mammary epithelial cells 

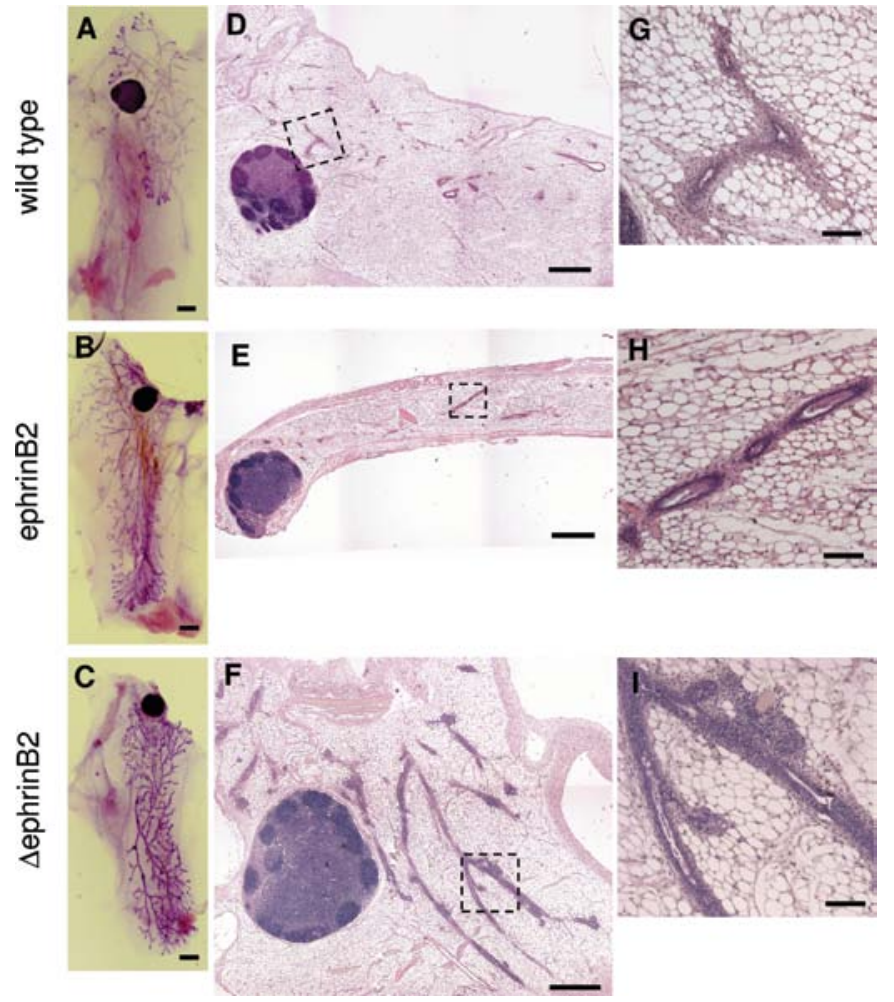

Figure 2. Morphology of epithelial outgrowths 8 weeks after injection derived from unsorted epithelial cells. (A-C) Wholemount staining of fat pads repopulated with epithelial cells isolated from wild-type (A), ephrinB2 (B) or $\Delta$ ephrinB2 (C) mammary glands. Scale bars represent $0.2 \mathrm{~cm}$. (D-I) Hematoxylin/eosin staining of sections from fat pads repopulated with epithelial cells isolated from mammary glands of wild-type (D and G), ephrinB2 $(E$ and $H)$ and $\Delta$ ephrinB2 (F and I) mice. Wild-type and ephrinB2 outgrowths exhibit normal ductal structures whereas outgrowths derived from $\Delta$ ephrinB2 cells show a thickened epithelium often lacking a lumen. Scale bars in (D-F) represent $800 \mu \mathrm{m}$, in (G-I) $100 \mu \mathrm{m}$.

(Fig. 2D, E, G and H). In contrast, hyperplastic, multilayered ducts, often without discernable lumen, were revealed by hematoxylin/eosin staining of $\Delta$ ephrinB2 derived outgrowths (Fig. 2F and I). Thus, although the mammary epithelium is enriched in cells capable of regenerating an epithelial network, their correct differentiation seems to be defective.

A first indication of impaired differentiation in the outgrowths derived from $\Delta$ ephrinB2 epithelial cells becomes apparent by analyzing cytokeratin 19 (K19) expression, a marker for undifferentiated epithelial cells, by confocal microscopy. Whereas the epithelial compartment of wild-type and also ephrinB2 (data not shown) derived outgrowths contained only single K19-positive cells mainly in growing ducts, most epithelial cells of the transgenic outgrowths exhibited K19 expression indicating their incomplete differentiation grade (Fig. 3A and D). K19-positive cells are thought to be not yet end-differentiated and still capable of proliferation. Cell proliferation analyzed by detection of Ki67 expression was rare in wild-type derived outgrowths (Fig. 3B and C) but highly abundant in the epithelium of transgenic outgrowths (Fig. 3E and F). The establishment of a functional mammary parenchyma is not only dependent on cell proliferation and differentiation but also on controlled apoptotic cell death. In particular, the formation of the alveolar and ductal lumen is effected by apop-

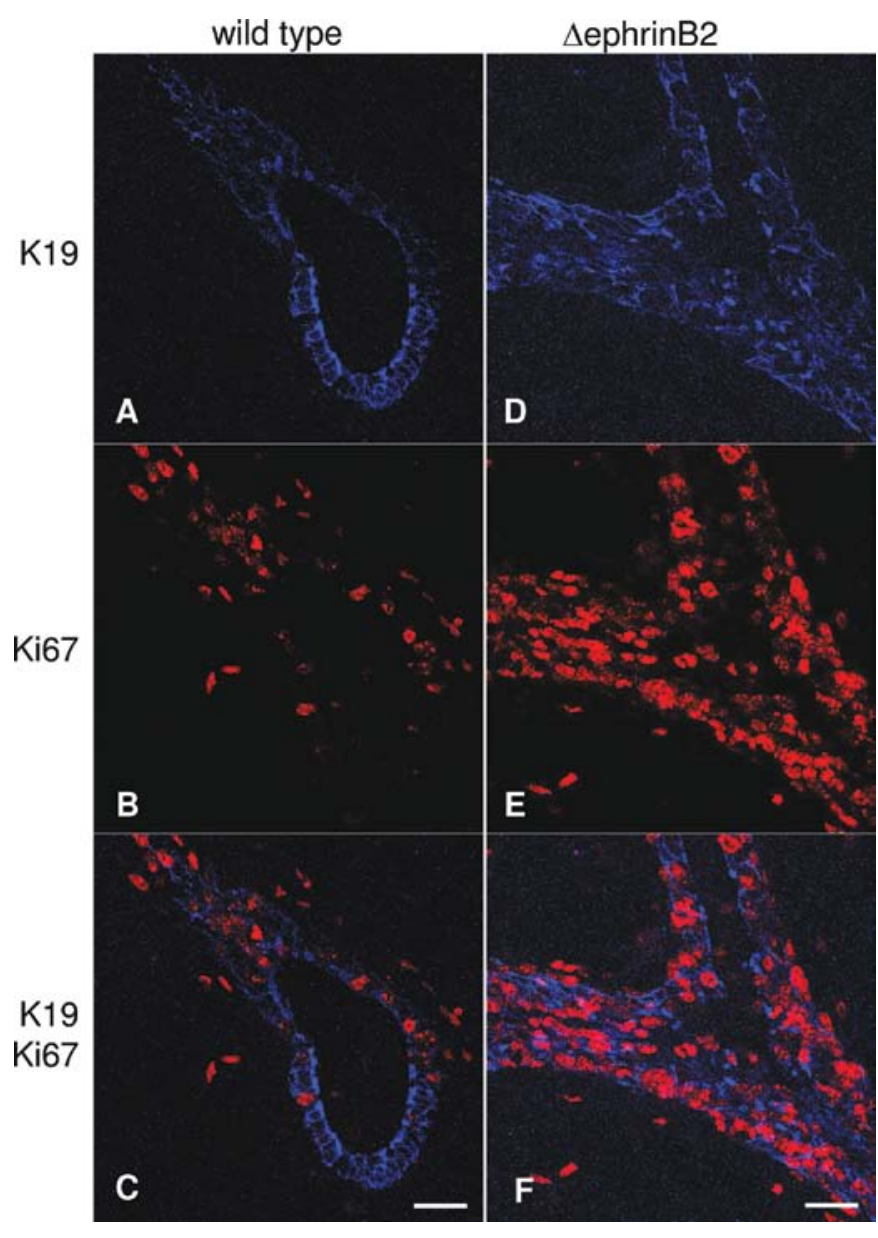

Figure 3. Cell proliferation in the outgrowths. Sections from fat pads repopulated with unsorted epithelial cells isolated from mammary glands of wild-type (A-C) and $\Delta$ ephrinB2 (D-F) mice reacted with anti-K19 and antiKi67 antibodies were analyzed by confocal microscopy. Scale bars represent $50 \mu \mathrm{m}$.

tosis of the central epithelial cells. Interestingly, quantification of activated caspase-3 expressing cells undergoing apoptosis revealed that ductal structures without lumen exhibited a significantly lower apoptotic activity in the transgenic than in the wild-type derived outgrowths $(2.1 \pm 0.9 \%$ and $6.7 \pm 1.5 \%$, respectively, $\mathrm{p}<0.001)$. These results may explain the frequent occurrence of hyperplastic regions and ducts without lumen in the outgrowths derived from $\triangle$ ephrinB2 cells.

To examine the perturbations of ductal architecture in more detail, sections of wild-type and the two transgenic derived outgrowths were analyzed by confocal microscopy for the expression of cyokeratin 18 (K18), the main cytokeratin of luminal epithelial cells, and cytokeratin 14 (K14), the major cytokeratin of the cells of the myopepithelial lineage. In the wild-type and the ephrinB2 outgrowths, the ducts exhibit defined compartments of K18 expressing epithelial cells surrounded by a single cell layer of K14 positive cells (Fig. 4A-C and D-F). Although K14 expressing cells were also located in the outer cell layer of $\triangle$ ephrinB2 transgenic outgrowths, this layer was discontinuous and locally both compartments were intermingled (Fig. 4G-I). The cells accumulating between the parenchyma and stroma were negative for the expression of both cytokeratins. These results indicate that epithelial cell differentiation and the determination of 


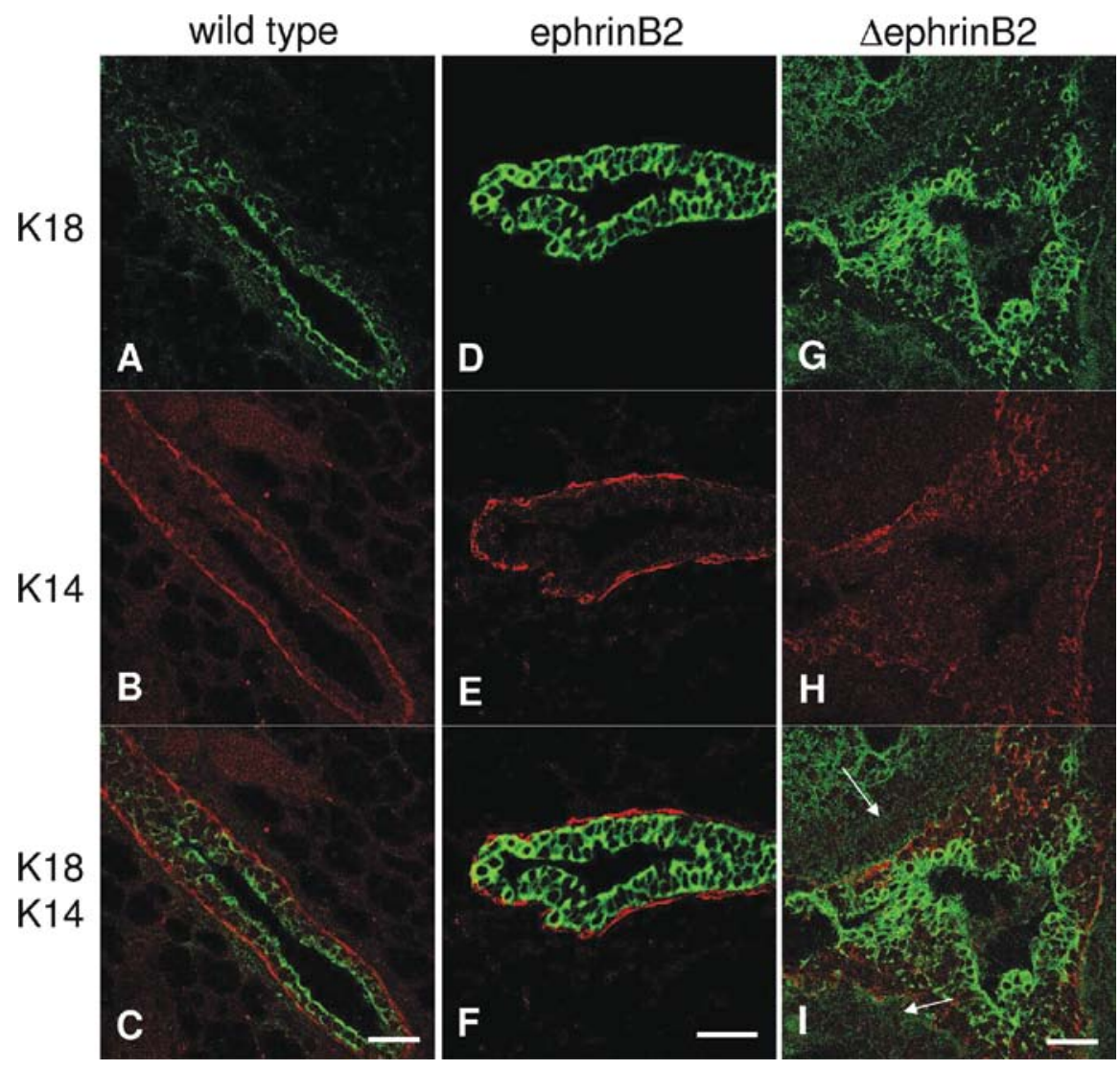

Figure 4. Organization of the parenchymal structure in outgrowths. Sections from fat pads repopulated with unsorted epithelial cells isolated from mammary glands of wild-type (A-C), ephrinB2 (D-F) and $\Delta$ ephrinB2 (G-I) mice reacted with anti-CK18 and anti-CK14 antibodies were analyzed by confocal microscopy. Arrows indicate cell aggregates surrounding the parenchyma. Scale bars represent $40 \mu \mathrm{m}$.

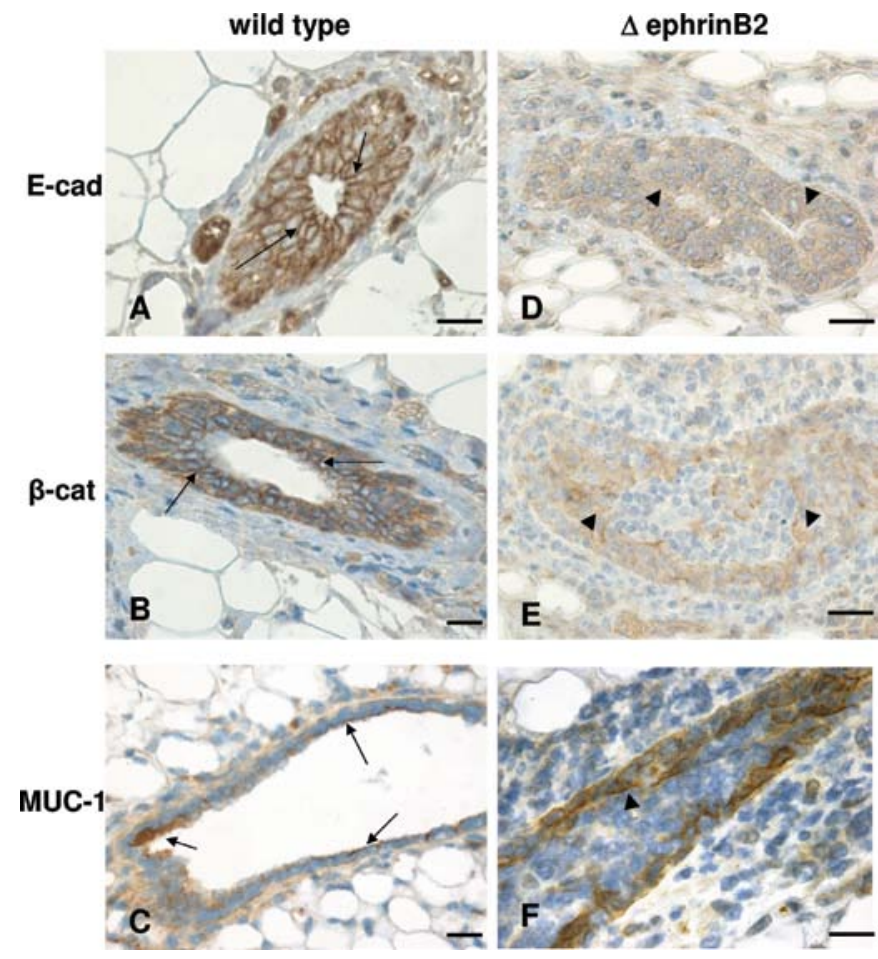

Figure 5. Immunohistochemical analysis of the outgrowth structures. Sections from fat pads repopulated with unsorted epithelial cells isolated from mammary glands of wild-type (A-C) and $\Delta$ ephrinB2 (D-F) mice were reacted with anti-E-cadherin (A and D), anti- $\beta$-catenin (B and $\mathrm{E})$ and anti-MUC-1 (C and F) antibodies. Arrows indicate normal and arrowheads aberrant protein localization. Scale bars represent $10 \mu \mathrm{m}$. cell identity are disturbed in outgrowths derived from stem/ progenitor cells of $\Delta$ ephrinB2 mammary glands. Since wildtype and ephrinB2 outgrowths were highly comparable, we have concentrated in the following on the comparison between the $\Delta$ ephrinB2 and wild-type derived outgrowth.

The integrity of the epithelial architecture was investigated by immunohistochemical detection of E-cadherin, $\beta$-catenin and Mucin-1 (MUC-1). E-cadherin and $\beta$-catenin, a protein complex critical for inter-epithelial communication and cell polarity, were detected in their correct localization on membranes of adjoining epithelial cells in ducts of outgrowths from wild-type cells (Fig. 5A and B). In contrast, mammary epithelial cells in outgrowths derived from transgenic mammary epithelial cells showed lower expression levels and rarely membrane localization of E-cadherin and $\beta$-catenin but rather a homogeneous cytoplasmic distribution (Fig. 5D and E), suggesting aberrant polarization and epithelial cell communication in these structures. MUC-1 is a transmembrane glycoprotein characteristic for the luminal barrier of differentiated mammary epithelial cells. In ducts of wild-type derived epithelial outgrowths, the MUC-1 protein was localized at the apical side of luminal epithelial cells indicating that these cells underwent correct differentiation (Fig. 5C). Strikingly, in outgrowths derived from transgenic mammary epithelial cells, strong MUC-1 expression was observed in a distinct layer of epithelial cells luminally surrounded by MUC-1 negative cells (Fig. 5F). In the MUC-1 expressing cells, the protein did not concentrate at the apical side of the cells, but rather was 


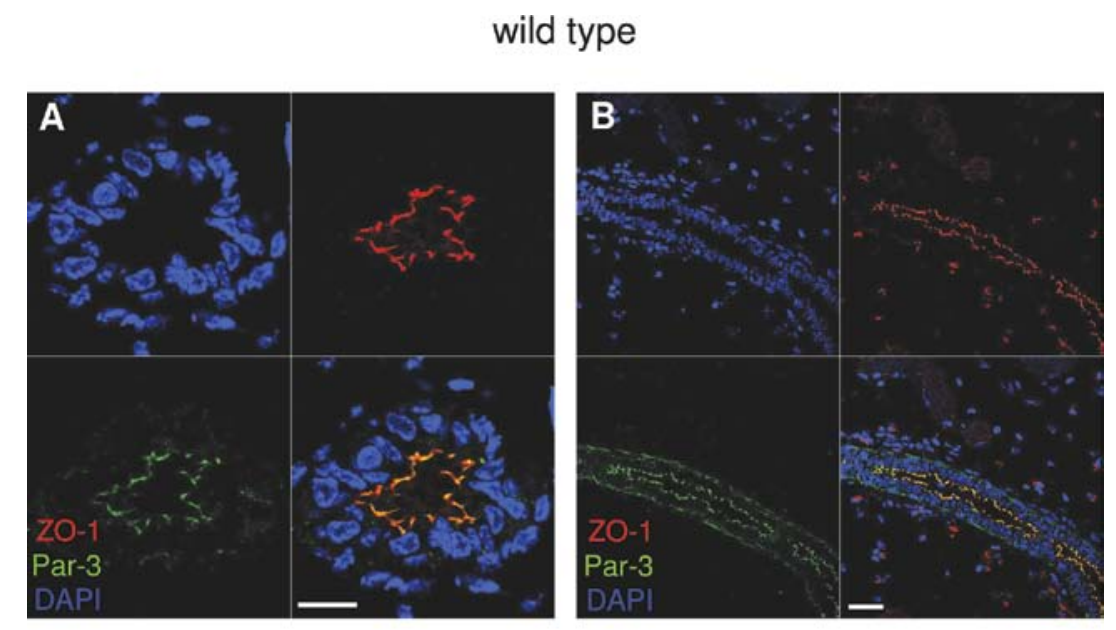

$\Delta$ ephrinB2
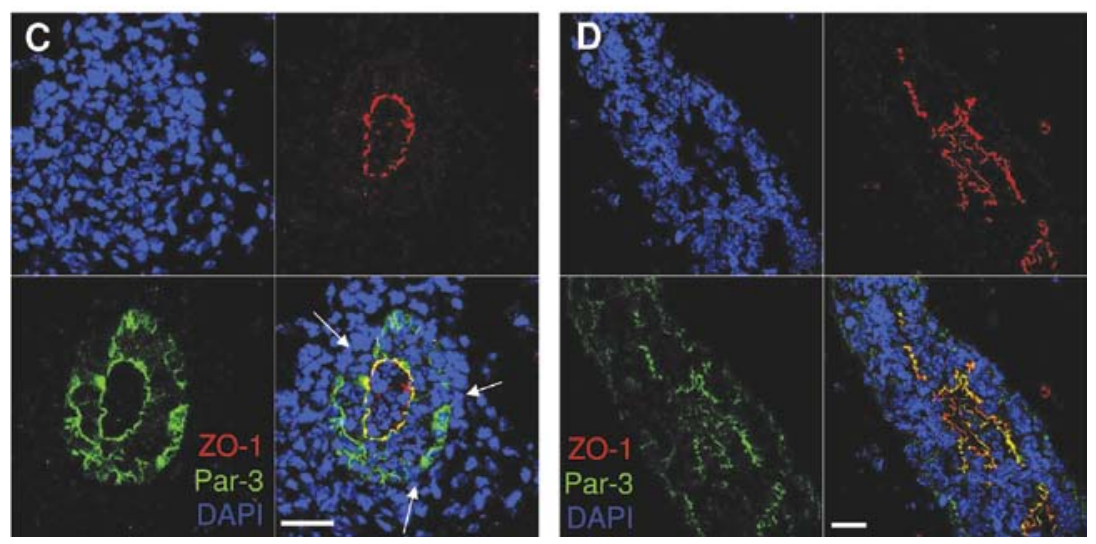

Figure 6. Polarity state of the parenchymal cells in outgrowths. Sections from fat pads repopulated with unsorted epithelial cells isolated from mammary glands of wild-type (A and B) and $\triangle$ ephrinB2 (C and D) mice reacted with anti-Par-3 and anti-ZO-1 antibodies were analyzed by confocal microscopy. Nuclei were counter-stained with DAPI. (A and C) show cross sections, (B and D) show longitudinal sections of mammary ducts. Arrows indicate cells disrupting a continuous layer of Par-3 expressing cells. Scale bars represent $40 \mu \mathrm{m}$.

present on the entire membrane, consistent with a failure in polarization. Furthermore, the stromal cell layer surrounding the ducts of wild-type outgrowths was replaced by chaotic cell accumulations with loose boundaries to the adipose tissue.

The failure of correct polarization in the outgrowths of the $\Delta$ ephrinB2 mammary epithelial cells was confirmed by confocal microscopy using anti-ZO-1 and anti-Par-3 antibodies. Par-3 and ZO-1 in normal mammary glands colocalize in the apical cell layers of mammary ducts as shown in cross and longitudinal sections (Fig. 6A and B). Low expression of Par-3 is additionally found in the basal cell layer of control outgrowths. Outgrowths derived from $\Delta$ ephrinB2 cells show a disturbed localization of both Par-3 and ZO-1 (Fig. 6C and D). In a cross section of a mammary duct lacking a lumen, there is a cell layer expressing both Par-3 and ZO-1, yet there is no complete overlap. Furthermore, high Par-3 expression with random distribution is observed in cells basal to the luminal cell layer, pointing toward a defective cell compartmentalization with aberrant localization of cell polarity regulators. This is also supported by the absent continuous distinction to the surrounding cells (Fig. 6C). In a longitudinal section the imperfect separation of luminal and basal cell layers becomes obvious where cell groups express polarity markers in a chaotic pattern and cells seem to form kind of tight-junctions in the absence of Par-3 (Fig. 6D).

In Par-3 depleted stem/progenitor cells, interaction of Par-3/ aPKC and subsequent apical localization of the complex has recently been shown to be critical in TEB organization, duct formation and progenitor differentiation (37). Thus it was of interest to analyze cell fate determination into steroid receptor positive or negative lineages among luminal cells, which is suggested to be represented by Sca-1 expression $(29,38)$. Confocal microscopy revealed that Sca-1 positive cells were rarely detected within the EpCAM positive cells of wild-type derived outgrowths. In contrast, Sca-1/EpCAM double positive cells could readily be observed in the transgenic outgrowths (Fig. 7A). This suggests that in $\Delta$ ephrinB2 outgrowths a shift towards estrogen receptor $\alpha(\mathrm{ER} \alpha)$ positive precursors took place. Quantification of ER $\alpha$ positive cells revealed their significant increase in the transgenic outgrowths compared to wild-type structures (data not shown).

In order to investigate if the increase of Sca-1 positive cells was already present in transgenic mammary glands or 
A
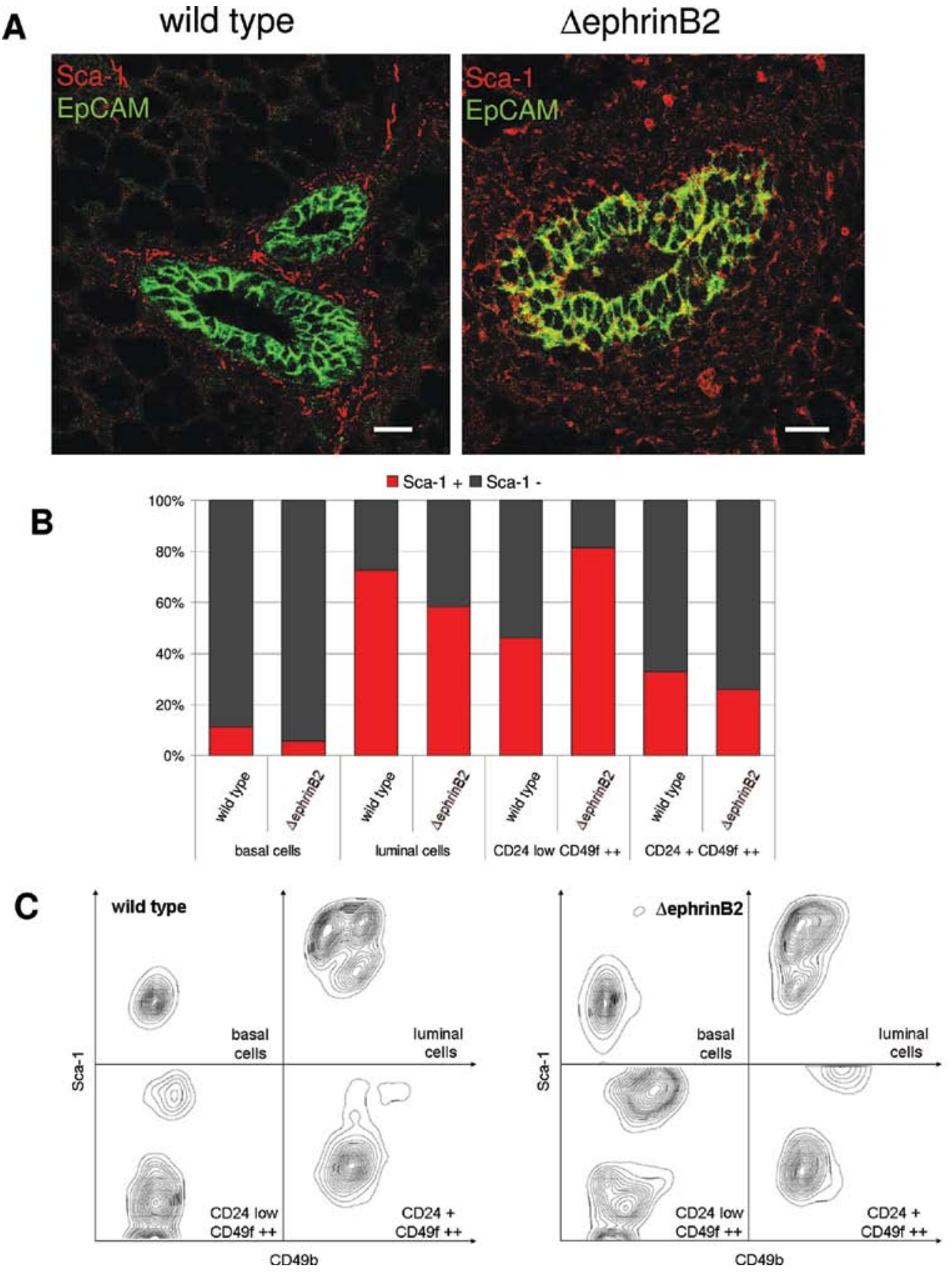

Figure 7. Characterization of Sca-1 expressing epithelial cells in mammary glands of wild-type and $\Delta$ ephrinB2 mice. (A) Sections from fat pads repopulated with unsorted epithelial cells isolated from mammary glands of wild-type and $\Delta$ ephrinB2 mice reacted with anti-Sca-1 and anti-EpCAM antibodies were analyzed by confocal microscopy. Scale bars represent $20 \mu \mathrm{m}$. (B) Quantification of Sca-1 expressing cells within the four cell populations gated with CD24 and CD49f as shown in Fig. 1A, N=6. (C) Representative contour plots of epithelial cells characterized by CD49b against Sca-1 expression within the four populations gated with CD24 and CD49f as shown in Fig. 1A.

is a consequence of the outgrowth process, we quantified Sca-1 expressing cells by FACS analysis in the four different cell populations defined by their CD24 and CD49f expression (Fig. 1A). These analyses indicated that the increase of Sca-1 positive cells could mainly be attributed to their preponderance in the stem cell-enriched fraction (Fig. 7B). Combining Sca-1 expression with CD49b expression, the integrin- $\alpha 2$ thought to represent a marker of luminal precursor cells (39), confirmed the increase of Sca-1 positive cells in the stem cell-enriched fraction (Fig. 7C). The CD $24^{+} / \mathrm{CD} 49 \mathrm{f}^{++}$progenitor cell-enriched fraction and the basal cell compartment did not differ in respect to Sca-1 and CD49b expression between the two experimental groups.
A striking difference, however, could be seen in the luminal cell fraction. Whereas the luminal epithelial cells of wild-type mammary glands were clearly divided into three distinct groups $\left(\mathrm{Sca}-1^{+} / \mathrm{CD}_{49} \mathrm{~b}^{\text {low }}, \mathrm{Sca}-1^{+} / \mathrm{CD}_{49 b^{+}}\right.$and $\mathrm{Sca}-1^{-} /$ $\mathrm{CD}_{49} \mathrm{~b}^{+}$), the luminal cells of transgenic mammary glands exhibited only two populations most probably at the expense of CD49b-positive cells supporting the aberrant differentiation in this cell compartment (Fig. 7C). These results indicate that the truncated ephrin-B2 expression leads to a shift of the mammary epithelial differentiation towards ER $\alpha$-positive precursor cells. Interestingly, quantification of ER $\alpha$-positive epithelial cells in transgenic and wild-type mature virgin mammary glands 


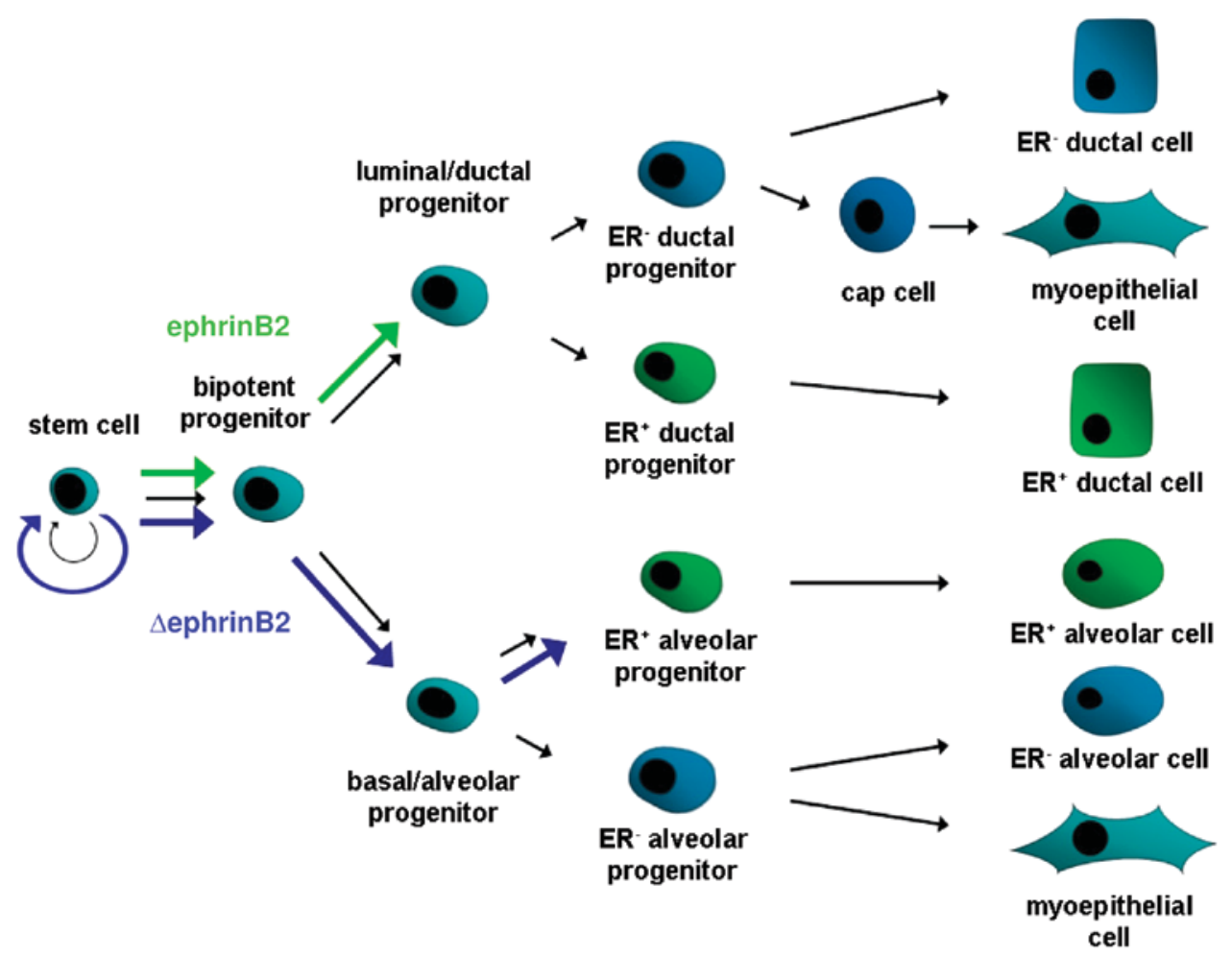

Figure 8. Schematic model of the interaction of ephrin-B2 with the mammary epithelial cell hierarchy. Normal developmental progress is represented by black arrows and influences of ephrin-B2 overexpression or truncated ephrin-B2 expression are highlighted by green or blue arrows, respectively.

revealed no difference in ductal structures $(34.2 \pm 6.3 \%$ vs $31.6 \pm 9.5 \%$, respectively), however, a significant increase of ER $\alpha$-positive cells in the alveoli of transgenic females (34.6 $\pm 7.3 \%$ vs. $23.8 \pm 3.6 \%$; $\mathrm{p}=0.02)$.

\section{Discussion}

The ability of a cell to give rise to an entire functional epithelial network in an epithelial-free mammary stroma has been generally accepted as proof of its stem cell identity. Similar repopulation assays involving defined epithelial sub-populations have allowed the development of models illustrating the differentiation hierarchy within the epithelial cell compartment (27,40-45). Transplantations of distinct mammary cell populations have revealed stages of clonal restrictiveness from mammary progenitor cells and have supported a hierarchical classification descending from a common stem, to bi-potent progenitor cells, and to their ductal/luminal and alveolar/basal progeny. After the separation of these lineages, both alveolar and ductal cells segregate into either estrogen receptor-positive or -negative cells.

The differentiation scheme presented in Fig. 8 illustrates a model of epithelial commitment and differentiation as it was recently summarized in an excellent review by Visvader and Smith (28). Within the context of this model of the epithelial cell hierarchy, our results suggest that overexpression of a truncated dominant negative mutant ephrin-B2 gene in the mammary epithelium leads to an increase of the mammary stem cells and the bi-potent progenitor cells. Differentiation from this cell pool towards the basal/alveolar compartment appears to be favoured since this cell population is also significantly more abundant in the mammary glands of the transgenic mice. In contrast, overexpression of the native ephrin-B2 gene seems to promote the differentiation pathway towards the luminal phenotype but leaves the stem cell pool unaffected.

The notion that the mammary epithelium of the $\Delta$ ephrinB2 females is enriched in stem cells is not only derived from quantitative FACS analyses but is also supported by the fact that this cell population is capable of regenerating an entire ductal tree and this with small cell concentrations. In addition, transgenic outgrowths were further advanced in the invasion of the fat pad than the control, and exhibited acinar structures at the expense of TEBs as well as considerable secondary and tertiary side branching. This suggests that in addition to their increased number, the transgenic stem cells also exhibit an increased and accelerated growth potential compared to the wild-type derived cells. This appears contradictory to previous findings where pubertal outgrowth of the embryonic epithelial anlagen was delayed in $\Delta$ ephrinB2 mice (4), yet in our current experimental setting stem and progenitor cells have been isolated from adult tissue which are susceptible to different signaling cues than cells layed down during embryonal morphogenesis (2).

In contrast to $\Delta$ ephrinB2 outgrowths, wild-type derived and ephrinB2 outgrowths were characterized by the typical pubertal morphology with abundant TEBs and as yet low number of side branches. In addition, wild-type and ephrinB2 cells often gave rise to cell clumps which appeared to be dormant, needing either more time to form their growthpromoting microenvironment or an activating stimulus. Of note, these cells were negative for all epithelial cell markers tested (data not shown) and it will be interesting to look at the influence of hormonal stimulation during pregnancy as they might depend on progesterone stimulation for proliferation and differentiation. A recent study reported that progesterone 
signaling mediated by Wnt4 and RANKL is responsible for the dynamics in the regulation of the mammary stem cell pool as well as the proliferation rate and differentiation in the niche during the reproductive cycle (17).

Members of the Eph and ephrin family have been shown to influence stem cells and their environment in a variety of organs and tissues. Bone homeostasis, asymmetric cell division of notochord/neural precursors, stem cells in dental tissue and especially the migration and proliferation of intestinal stem cells are directly regulated or influenced by Eph/ephrin signaling (46-49). Epithelial function in the mammary gland requires an operational architecture with correct compartmentalization. Although a certain functionality of the gland was maintained in the $\Delta$ ephrinB2 females, severe structural defects were apparent (4).

In the analysis of the outgrowths, we concentrated on the analysis of marker proteins which are indicative for cell compartmentalization and proper differentiation. We found that growth of $\Delta$ ephrinB2 epithelial cells in a normal, wild-type mammary fat pad gives rise to outgrowths that lack the correct organization of luminal and basal cells. These abnormalities point to either a common defect early in the establishment of cell identity or to the diversity of mechanisms impaired by the dominant negative ephrin-B2 expression. Differentiation disorders in the luminal and basal compartment are manifest especially in the K18/K14 expression. The absence of these markers in their normal localization illustrates cells which are not responsive to environmental cues or which are unable to undergo required cellular differentiation. Interaction of the myoepithelium with the luminal compartment has been shown to be important for correct growth and differentiation of both partners $(50,51)$.

We observed cells accumulating outside of, or within these compartments, which did not express any of the lineage specific markers suggesting that a subset of cells was incapable of attaining any identity. Whether the differentiation defects on myoepithelial and luminal epithelial cells emanate from only one of these populations or whether they are independently deregulated in both compartments remains unknown.

E-cadherin, whose membrane localization and intracellular association is critical for apical-basal polarity of mammary epithelial cells, is not detected on membranes of $\Delta$ ephrinB2 outgrowths and consequently, also $\beta$-catenin is not membraneassociated. Moreover, the MUC-1 protein was not detected at its normal apical localization. An impaired polarity state is thus a probable mechanism for the disturbed luminal differentiation. It has been shown that E-cadherin mediated cell-cell adhesion can regulate Eph-ephrin expression and membrane localization (32) and vice versa that EphB-ephrin-B signaling recruits E-cadherin to the cell membrane (33). Thus, deregulation of this feedback in the mammary epithelium or even direct cross-talk between truncated ephrin-B2 and E-cadherin could have led to the observed effect on cell polarity in the transgenic outgrowths. This, in turn, would promote not only the disturbances in differentiation processes but also would affect the lumen formation of the growing ducts. Lumen formation in the mammary epithelium is preceeded by polarization of the outer ring of epithelial cells, depleting the inner cell mass from contact with and signals from the ECM inducing their programmed cell death by anoikis (52).
Par-3 is a member of the core polarity regulator PAR complex (Par-3, Par-6, aPKC, Cdc42) and its transport/ localization represents an initiator of apical-basal polarity of epithelial cells and an essential component of the recruitment of ZO-1. ZO-1 in turn constitutes and maintains the tight junctions of polarized epithelial cells. The confocal analyses of these two proteins revealed severe perturbations in their expression and sub-cellular co-localization which might have led to the observed reduction in apoptotic cell death and lumen formation in the $\Delta$ ephrinB2 outgrowths. It has been shown that ephrin-B1 reverse signaling not only is controlled by and regulates adherens junctions but is also involved in the establishment of functional tight junctions (39). Furthermore, screening for PDZ-interacting proteins of ephrins-B1-3 revealed a Par-3 homolog to be a major ephrin-interacting protein (53).

Of note, a recent study demonstrates that ephrin-B2 reverse signaling controls septation events at the embryonic midline and the authors proposed the interaction of ephrin-B2 with Par-3 as a possible PDZ-dependent mechanism by which ephrin reverse signaling affects embryonic midline formation (54). It is conceivable that in the mammary epithelium ephrin-B2 reverse signaling is similarly important for cell polarization either by affecting Par-3/cadherin mediated formation of adherens junctions and/or by directly regulating the formation of tight junction complexes via interaction with Par-3 and/or Par-6. Moreover, the failure of generating appropriate cell-cell contacts would also influence the maintenance of the stem cell niche, thereby altering the regenerative activity of mammary stem and progenitor cells.

As the parenchyma of the mammary gland in its developmental progression is dependent on hormonal stimulation, the link of Eph/ephrin signaling to hormonal regulation is intriguing. We have previously described that the expression of EphB4 but not of ephrin-B2 is induced by estrogen (55). In this study, we describe the prevalence of Sca-1 and also ER-positive epithelial cells in $\Delta$ ephrinB2 mammary glands and outgrowths. This observation raises the important issue of the mutual role of ER and Eph-ephrin signaling in mammary epithelial homeostasis. Conceivably, estrogen induces the expression of EphB4, which then by interaction with ephrin-B2 is involved in the restriction of the development of ER $\alpha$ positive (sensor) cells. Of note, the enrichment of Sca-1 positive cells was mainly restricted to the stem cell enriched population thought to be devoid of this cell type. It remains to be elucidated, if the stem cell population does normally contain a few ER $\alpha$-positive precursors, as proposed by Visvader and Smith (28), which are augmented by the block of ephrin-B2 signaling. Alternatively, the inhibited ephrin-B2 signaling may have induced a reprogramming of stem cells to an ER $\alpha$-positive status. In this context, another interesting aspect lies in the role hormonal regulation has on the mammary stem and progenitor cell pool regulation. ER $\alpha$ expression is thought to be absent on the most potent cells of the epithelial cell hierarchy but in a paracrine manner estrogen stimulation appears as an important factor given the mammary stem cell responsiveness as described recently by Asselin-Labat et al (56). During carcinogenesis of ER $\alpha$-positive breast cancers, $\mathrm{ER} \alpha$ expression is increased at the very earliest stages of ductal hyperplasia and is further augmented with increasing atypia. Subsequently most cells in atypical ductal hyperplasias and in ductal carcinomas in situ (DCIS) of low and intermediate 
nuclear grade contain the ER $\alpha$ (57). Concomitant with increased expression of ER $\alpha$ these cells become more deregulated and, in contrast to their normal behaviour, highly proliferative (58).

Previous studies indicate that the majority of ER $\alpha$-positive cells are proliferating in the malignant invasive receptor positive breast carcinomas (59). Although none of our $\Delta$ ephrinB2 expressing transgenic females developed mammary tumors, the development of metastases from non-metastatic NeuT-induced tumors by blocking ephrin-B2 signaling (3), together with the increase of ER $\alpha$-positive, proliferating cells in the transgenic epithelium and outgrowths suggests a similar regulatory failure during carcinogenesis and tissue regeneration. Since proper growth control of regenerating mammary epithelial cells depends on intact cell communication in the microenvironment (60), the deregulated ephrin-B2 signaling may have provoked resistance to or misinterpretation of environmental cues.

In summary, our results indicate that the defective ephrinB2 signaling in the mammary epithelium leads to perturbation of the stem cell niche, to a shift in the differentiation pathway and to a defective tissue compartmentalization. Augmentation of the stem cell pool, increased numbers of ER $\alpha$-positive (sensory) cells and reduced cell polarity and cell contacts, although per se not sufficient for cellular transformation, most probably provoked the metastatic phenotype once tumorigenesis was initiated. Since overexpression of the native ephrin-B2 gene led to a shift of the differentiation pathway towards the luminal phenotype, whereas truncated ephrin-B2 promoted the basal differentiation pathway, the correct differentiation decisions may depend on a balanced Eph-ephrin-B2 forward and reverse signaling. In contrast, the stem cell compartment was affected by truncated ephrin-B2 only, indicating that mainly the reverse signaling is instrumental in stem cell regulation. To our knowledge, this is the first demonstration that intact EphB4-ephrin-B2 signaling is mandatory for the regulation of the mammary stem cell niche, mammary regeneration and thereby for the homeostasis of the mammary epithelium.

\section{Acknowledgements}

This study was supported by the Swiss National Science Foundation (3100A0-127168), the Swiss Cancer League (KLS-02105-08-2007) and the Schweizerische Stiftung für Klinisch-Experimentelle Tumorforschung.

\section{References}

1. Zhou BB, Zhang H, Damelin M, Geles KG, Grindley JC and Dirks PB: Tumour initiating cells: challenges and opportunities for anticancer drug discovery. Nat Rev Drug Disc 8: 806-823, 2009.

2. Brisken C and Duss S: Stem cells and the stem cell niche in the breast: an integrated hormonal and developmental perspective. Stem Cell Rev 3: 147-156, 2007.

3. Kaenel P, Schwab C, Mulchi K, Wotzkow C and Andres AC: Preponderance of cells with stem cell characteristics in metastasising mouse mammary tumours induced by deregulated EphB4 and ephrin-B2 expression. Int J Oncol 38: 151-160, 2011.

4. Haldimann M, Custer D, Munarini N, Stirnimann C, Zurcher G, Rohrbach V, Djonov V,Ziemiecki A and Andres AC: Deregulated ephrin-B2 expression in the mammary gland interferes with the development of both the glandular epithelium and vasculature and promotes metastasis formation. Int $\mathrm{J}$ Oncol 35: 525-536, 2009.
5. Munarini N, Jager R, Abderhalden S, Zuercher G, Rohrbach V, Loercher S, Pfanner-Meyer B, Andres AC and Ziemiecki A: Altered mammary epithelial development, pattern formation and involution in transgenic mice expressing the EphB4 receptor tyrosine kinase. J Cell Sci 115: 25-37, 2002.

6. Sternlicht MD: Key stages in mammary gland development: the cues that regulate ductal branching morphogenesis. Breast Cancer Res 8: 201, 2006.

7. McDaniel SM, Rumer, KK, Biroc SL, Metz RP, Singh M, Porter W and Schedin P: Remodeling of the mammary microenvironment after lactation promotes breast tumor cell metastasis. Am J Pathol 168: 608-620, 2006.

8. Howlin J, McBryan J and Martin F: Pubertal mammary gland development: insights from mouse models. J Mammary Gland Biol Neoplasia 11: 283-297, 2006.

9. Silberstein GB: Postnatal mammary gland morphogenesis. Microsc Res Tech 52: 155-162, 2001.

10. Kametani Y and Takeichi M: Basal-to-apical cadherin flow at cell junctions. Nat Cell Biol 9: 92-98, 2007.

11. Schwertfeger KL, Rosen JM and Cohen DA: Mammary gland macrophages: pleiotropic functions in mammary development. J Mammary Gland Biol Neoplasia 11: 229-238, 2006.

12. Dunbar ME and Wysolmerski JJ: Parathyroid hormone-related protein: a developmental regulatory molecule necessary for mammary gland development. J Mammary Gland Biol Neoplasia 4: 21-34, 1999.

13. Hens JR, Dann P, Zhang JP, Harris S, Robinson GW and Wysolmerski J: BMP4 and PTHrP interact to stimulate ductal outgrowth during embryonic mammary development and to inhibit hair follicle induction. Development 134: 1221-1230, 2007.

14. Chu EY, Hens J, Andl T, Kairo A, Yamaguchi TP, Brisken C, Glick A, Wysolmerski JJ and Millar SE: Canonical WNT signaling promotes mammary placode development and is essential for initiation of mammary gland morphogenesis. Development 131: 4819-4829, 2004.

15. Mailleux AA, Spencer-Dene B, Dillon C, Ndiaye D, SavonaBaron C, Itoh N, Kato S, Dickson C, Thiery JP and Bellusci S: Role of FGF10/FGFR2b signaling during mammary gland development in the mouse embryo. Development 129: 53-60, 1998.

16. Brisken C, Park S, Vass T, Lydon JP, O'Malley BW and Weinberg RA: A paracrine role for the epithelial progesterone receptor in mammary gland development. Proc Natl Acad Sci USA 95: 5076-5081, 1998.

17. Joshi PA, Jackson HW, Beristain AG, Di Grappa MA, Mote PA, Clarke CL, Stingl J, Waterhouse PD and Khokha R: Progesterone induces adult mammary stem cell expansion. Nature 465: 803-807, 2010.

18. Mallepell S, Krust A, Chambon P and Brisken C: Paracrine signaling through the epithelial estrogen receptor alpha is required for proliferation and morphogenesis in the mammary gland. Proc Natl Acad Sci USA 103: 2196-2201, 2006.

19. Brisken C, Heineman A, Chavarria T, Elenbaas B, Tan J, Dey SK, McMahon JA, McMahon AP and Weinberg RA: Essential function of Wnt-4 in mammary gland development downstream of progesterone signaling. Genes Dev 14: 650-654, 2000.

20. Cao Y, Bonizzi G, Seagroves TN, Greten FR, Johnson R, Schmidt EV and Karin M: IKKalpha provides an essential link between RANK signaling and cyclin D1 expression during mammary gland development. Cell 107: 763-775, 2001.

21. Ciarloni L, Mallepell S and Brisken C: Amphiregulin is an essential mediator of estrogen receptor alpha function in mammary gland development. Proc Natl Acad Sci USA 104: 5455-5460, 2007.

22. Rudland PS, Platt-Higgins AM, Wilkinson MC and Fernig DG: Immunocytochemical identification of basic fibroblast growth factor in the developing rat mammary gland: variations in location are dependent on glandular structure and differentiation. J Histochem Cytochem 41: 887-898, 1993.

23. Hinck L and Silberstein GB: Key stages in mammary gland development: the mammary end bud as a motile organ. Breast Cancer Res 7: 245-251, 2005.

24. Muschler J and Streuli CH: Cell-matrix interactions in mammary gland development and breast cancer. Cold Spring Harb Perspect Biol 2: a003202, 2010.

25. Ewan KB, Shyamala G, Ravani SA, Tang Y, Akhurst R, Wakefield $\mathrm{L}$ and Barcellos-Hoff $\mathrm{MH}$ : Latent transforming growth factor-beta activation in mammary gland: regulation by ovarian hormones affects ductal and alveolar proliferation. Am J Pathol 160: 2081-2093, 2002. 
26. Fata JE, Werb $\mathrm{Z}$ and Bissell MJ: Regulation of mammary gland branching morphogenesis by the extracellular matrix and its remodeling enzymes. Breast Cancer Res 6: 1-11, 2004.

27. Bruno RD and Smith GH: Functional characterization of stem cell activity in the mouse mammary gland. Stem Cell Rev 7: 238-247, 2011.

28. Visvader JE and Smith GH: Murine mammary epithelial stem cells: discovery, function, and current status. Cold Spring Harb Perspect Biol: doi: 10.1101/cshperspect.a004879, 2011.

29. Stingl J: Detection and analysis of mammary gland stem cells. J Pathol 217: 229-241, 2009.

30. Pasquale EB: Eph receptors and ephrins in cancer: bidirectional signalling and beyond. Nat Rev Cancer 10: 165-180, 2010.

31. Clevers $H$ and Batlle E: EphB/EphrinB receptors and Wnt signaling in colorectal cancer. Cancer Res 66: 2-5, 2006.

32. Orsulic S and Kemler R: Expression of Eph receptors and ephrins is differentially regulated by E-cadherin. J Cell Sci 113: 1793-1802, 2000.

33. Cortina C, Palomo-Ponce S, Iglesias M, et al: EphB-ephrin-B interactions suppress colorectal cancer progression by compartmentalizing tumor cells. Nat Genet 39: 1376-1383, 2007.

34. Andres A-C and Ziemiecki A: Eph and ephrin signaling in mammary gland morphogenesis and cancer. J Mammary Gland Biol Neoplasia 8: 475-485, 2003.

35. Weiler S, Rohrbach V, Pulvirenti T, Adams R, Ziemiecki A and Andres AC: Mammary epithelial-specific knockout of the ephrin-B2 gene leads to precocious epithelial cell death at lactation. Dev Growth Differ 51: 809-819, 2009.

36. Deome KB, Faulkin LJ Jr, Bern HA and Blair PB: Development of mammary tumors from hyperplastic alveolar nodules transplanted into gland-free mammary fat pads of female $\mathrm{C} 3 \mathrm{H}$ mice. Cancer Res 19: 515-520, 1959.

37. McCaffrey LM and Macara IG: The Par3/aPKC interaction is essential for end bud remodeling and progenitor differentiation during mammary gland morphogenesis. Genes Dev 23: 1450-1460, 2009.

38. Sleeman KE, Kendrick H, Robertson D, Isacke CM, Ashworth A and Smalley MJ: Dissociation of estrogen receptor expression and in vivo stem cell activity in the mammary gland. J Cell Biol 176: 19-26, 2007.

39. Lee HS, Nishanian TG, Mood K, Bong YS and Daar IO: EphrinB1 controls cell-cell junctions through the Par polarity complex. Nat Cell Biol 10: 979-986, 2008.

40. Asselin-Labat ML, Vaillant F, Shackleton M, Bouras T, Lindeman GJ and Visvader JE: Delineating the epithelial hierarchy in the mouse mammary gland. Cold Spring Harb Symp Quant Biol 73: 469-478, 2008.

41. Boulanger CA and Smith GH: Reprogramming cell fates in the mammary microenvironment. Cell Cycle 8: 1127-1132, 2009.

42. Sleeman KE, Kendrick H, Ashworth A, Isacke CM and Smalley MJ: CD24 staining of mouse mammary gland cells defines luminal epithelial, myoepithelial/basal and non-epithelial cells. Breast Cancer Res 8: R7, 2006.

43. Stingl J, Eirew P, Ricketson I, Shackleton M, Vaillant F, Choi D, Li HI and Eaves CJ: Purification and unique properties of mammary epithelial stem cells. Nature 439: 993-997, 2006.

44. Vaillant F, Asselin-Labat ML, Shackleton M, Lindeman GJ and Visvader JE: The emerging picture of the mouse mammary stem cell. Stem Cell Rev 3: 114-123, 2007.
45. Visvader JE: Keeping abreast of the mammary epithelial hierarchy and breast tumorigenesis. Genes Dev 23: 2563-2577, 2009.

46. Battle E, Henderson JT, Beghtel H, van den Born MM, Sancho E Huls G, Meeldijk J, Robertson J, van de Wetering M, Pawson T and Clevers H: Beta-catenin and TCF mediate cell positioning in the intestinal epithelium by controlling the expression of EphB/ ephrinB. Cell 111: 251-263, 2002.

47. Picco V, Hudson $\mathrm{C}$ and Yasuo $\mathrm{H}$ : Ephrin-Eph signalling drives the asymmetric division of notochord/neural precursors in Ciona embryos. Development 134: 1491-1497, 2007.

48. Stokowski A, Shi S, Sun T, Bartold PM, Koblar SA and Gronthos S: EphB/ephrin-B interaction mediates adult stem cell attachment, spreading, and migration: implications for dental tissue repair. Stem Cells 25: 156-164, 2007.

49. Zhao C, Irie N, Takada Y, Shimoda K, Miyamoto T, Nishiwaki T, Suda T and Matsuo K: Bidirectional ephrinB2-EphB4 signaling controls bone homeostasis. Cell Metab 4: 111-121, 2006.

50. Faraldo MM, Teuliere J, Deugnier MA, Taddei-De La Hosseraye I, Thiery JP and Glukhova MA: Myoepithelial cells in the control of mammary development and tumorigenesis: data from genetically modified mice. J Mammary Gland Biol Neoplasia 10: 211-219, 2005.

51. Gudjonsson T, Ronnov-Jessen L, Villadsen R, Rank F, Bissell MJ and Petersen OW: Normal and tumor-derived myoepithelial cells differ in their ability to interact with luminal breast epithelial cells for polarity and basement membrane deposition. J Cell Sci 115: 39-50, 2001.

52. Andrew DJ and Ewald AJ: Morphogenesis of epithelial tubes: Insights into tube formation, elongation, and elaboration. Dev Biol 341: 34-55, 2010.

53. Lin D, Gish GD, Songyang Z and Pawson T: The carboxyl terminus of $\mathrm{B}$ class ephrins constitutes a PDZ domain binding motif. J Biol Chem 274: 3726-3733, 1999.

54. Dravis C and Henkemeyer M: Ephrin-B reverse signaling controls septation events at the embryonic midline through separate tyrosine phosphorylation-independent signaling avenues. Dev Biol 355: 138-151, 2011.

55. Nikolova Z, Djonov V,Zuercher G, Andres AC and Ziemiecki A: Cell-type specific and estrogen dependent expression of the receptor tyrosine kinase EphB4 and its ligand ephrin-B2 during mammary gland morphogenesis. J Cell Sci 111: 2741-2751, 1998.

56. Asselin-Labat ML, Vaillant F, Sheridan JM, Pal B, Wu D, Simpson ER, Yasuda H, Smyth GK, Martin TJ, Lindeman GJ and Visvader JE: Control of mammary stem cell function by steroid hormone signalling. Nature 465: 798-802, 2011.

57. Shoker BS, Jarvis C, Clarke RB, Anderson E, Hewlett J, Davies MP, Sibson DR and Sloane JP: Estrogen receptor-positive proliferating cells in the normal and precancerous breast. Am J Pathol 155: 1811-1815, 1999.

58 Shoker BS, Jarvis C, Sibson DR, Walker C and Sloane JP: Oestrogen receptor expression in the normal and pre-cancerous breast. J Pathol 188: 237-244, 1999.

59. Clarke RB, Howell A, Potten CS and Anderson E: Dissociation between steroid receptor expression and cell proliferation in the human breast. Cancer Res 57: 4987-4991, 1997.

60. Bissell MJ and Labarge MA: Context, tissue plasticity, and cancer: are tumor stem cells also regulated by the microenvironment? Cancer Cell 7: 17-23, 2005. 